\title{
POTENSI BIOLOGI BIJI PEPAYA (Carica papaya L.) DALAM UPAYA PENINGKATAN KINERJA ITIK RAJA
}

\section{BIOLOGICAL POTENCY OF Carica papaya L. SEED FOR IMPROVING “RAJA” DUCK PERFORMANCE}

\author{
Rini Rachmatika* dan Siti Nuramaliati Prijono \\ Pusat Penelitian Biologi-Lembaga Ilmu Pengetahuan Indonesia, Cibinong, 16911
}

Submitted: 26 June 2014, Accepted: 2 January 2015

\section{INTISARI}

Penelitian ini bertujuan untuk mengkaji kinerja itik Raja yang diberi biji pepaya segar dalam pakannya. Ternak yang digunakan adalah itik Raja yang berumur 7 hari. Penelitian menggunakan Rancangan Acak Lengkap pola searah dengan 4 perlakuan dan 3 replikasi, setiap replikasi 6 ekor itik. Apabila perlakuan menunjukkan signifikansi maka dilanjutkan dengan Duncan's Multiple Range Test. Perlakuan yang diberikan yaitu $\mathrm{T0}=0 \%$ (kontrol), $\mathrm{T} 1=0,3 \%$ biji pepaya dalam ransum, $\mathrm{T} 2=0,6 \% \mathrm{biji}$ pepaya dalam ransum, dan T3 $=1,2 \%$ biji pepaya dalam ransum. Variabel yang diamati meliputi konsumsi pakan, pertambahan berat badan, dan konversi pakan. Hasil penelitian menunjukkan bahwa penggunaan biji pepaya sampai level 1,2\% menurunkan konsumsi pakan, namun menaikkan pertambahan bobot badan, sehingga diperoleh nilai konversi pakan yang lebih baik $(P<0,05)$. Hasil penelitian menunjukkan bahwa penambahan biji pepaya dalam pakan sebanyak $1,2 \%$ berpotensi meningkatkan kinerja itik Raja.

(Kata kunci: Biji pepaya, Itik, Kinerja, Konversi pakan)

\section{ABSTRACT}

This experiment was conducted to evaluate the effect of papaya seed in feed on Raja duck's performance. Experimental animals were 72 birds of 7 days old Raja ducks. Variables observed were feed intake, body weight gain, and feed conversion ratio. Experiment was assigned in one way of Completely Randomized Design with four treatments and three replication (six birds each). The treatments diets were $T 0=$ basal diets without papaya seed, $T 1=0.3 \%, T 2=0.6 \%$, and $T 3=1.2 \%$ papaya seed. Dietary treatment were provided until 45 days of age. Data were subjected to analysis of variance using SPSS 16.0 and continued with Duncan's Multiple Range Test for all significant results at $5 \%$ level of probability. Result showed that feeding diets with $1.2 \%$ papaya seed supplementation reduced feed intake but increased body weight gain, resulted in better feed conversion ratio $(P<0.05)$. It might indicate that papaya seed has potency to improve performance of Raja ducks.

(Key words: Duck, Feed conversion ratio, Papaya seed, Performance)

\section{Pendahuluan}

Pemenuhan sumber protein hewani yang semakin meningkat sebagai salah satu nutrien penting bagi manusia mutlak harus dipenuhi, hal itu seiring meningkatnya kesadaran masyarakat tentang pentingnya peningkatan gizi keluarga. Daging unggas seperti ayam broiler dan itik kerap menjadi pilihan sebagai sumber protein hewani karena harganya yang relatif terjangkau. Selain itu, unggas memiliki pertumbuhan yang cepat,

\footnotetext{
${ }^{*}$ Korespondensi (corresponding author):

Telp. +62 81514032517

E-mail: r.rachmatika@gmail.com
}

sehingga lebih cepat dipanen untuk pemenuhan kebutuhan pasar.

Saat ini, kecenderungan masyarakat dalam mengkonsumsi daging itik mulai mengalami peningkatan. Hal itu ditandai dengan terus meningkatnya populasi itik di Indonesia sejak Tahun 2008 hingga 2012. Pada Tahun 2008 populasi ternak itik 39.840.000 ekor, meningkat di Tahun 2012 mencapai 46.990 .000 ekor. Hal itu diiringi dengan meningkatnya angka ekspor itik dari tahun 2008 sampai 2012. Produksi daging itik pun meningkat dari Tahun 2009 sebesar 25.800 ton dan pada Tahun 2012 sebesar 30.800 ton (Anonim, 2012). 
Itik Raja adalah adalah sebutan bagi itik jantan dari itik MA 2.000 yang merupakan hasil persilangan antara itik Alabio dengan itik Mojosari. Itik Raja merupakan keturunan F1 yang memiliki keunggulan dibandingkan dengan tetuanya dan sangat cocok untuk dikembangkan di Indonesia sebagai itik pedaging dalam rangka memenuhi kebutuhan protein hewani asal unggas bagi masyarakat (Susanti, 2003). Bentuk tubuhnya menyerupai botol dengan postur agak berdiri tegak. Warna bulu cokelat kemerahan pada hampir seluruh tubuhnya, dengan bintik-bintik cokelat gelap pada bagian dada dan perut. Itik ini memiliki warna kaki dan paruh hitam dengan berat badan umur 6 minggu sebesar 1,2-1,4 kg/ekor (Kusumaningtyas, 2012).

Itik MA 2000 memiliki keunggulan yaitu umur pertama bertelur lebih awal, produksi bertelur lebih tinggi, konsistensi produksi lebih baik, pertumbuhan lebih cepat, anak jantan dapat dijadikan penghasil daging bila dibandingkan dengan anak itik Mojosari dan itik Alabio. Kebutuhan gizi pakan itik pada umur 0-8 minggu mengandung protein kasar $17-20 \%$, energi $3100 \mathrm{kcal} / \mathrm{kg}$, Ca 0,6-1,1\%, P tersedia $0,6 \%$. Keunggulan itik MA tersaji pada Tabel 1.

Pakan merupakan faktor penting dalam suatu pemeliharaan ternak itik. Komposisi nutrien dalam pakan akan menentukan keberhasilan pertumbuhan dan produksi telur maupun daging. Pakan pada itik peking terdapat dua fase, yaitu starter (0-2 minggu) dan finisher (2-7 minggu) (NRC, 1994). Pada fase starter diberikan pakan dengan kandungan protein 22\% dengan energi 2900 $\mathrm{kkal} / \mathrm{kg}$, dan pada fase finisher diberikan pakan dengan kandungan protein $16 \%$ dan energi $3000 \mathrm{kkal} / \mathrm{kg}$. Itik pedaging belum memiliki standar mutu pakan (SNI), maka untuk kebutuhan pakan itik pedaging yang berumur 1-21 hari dapat menggunakan pakan starter itik petelur dengan SNI Nomor 013908-1995 dengan kandungan protein kasar
$18-22 \%$ dan energi termetabolisme 3.000 $\mathrm{kcal} / \mathrm{kg}$. Untuk kebutuhan itik finisher dipergunakan pakan itik petelur dara sesuai dengan SNI Nomor 01-3909-1995 dengan kandungan protein kasar 15\% dan energi termetabolisme $2.700 \mathrm{kcal} / \mathrm{kg}$ (Anonim, 2007). Bentuk pakan yang cocok untuk itik adalah bentuk halus dan dalam bentuk basah. Bentuk paruh itik yang panjang dan bergerigi menyebabkan itik sulit untuk mengambil pakan halus kering. Hal tersebut dapat menyebabkan pakan tercecer (Hardjosworo dan Rukmiasih, 1999).

Maisarah et al. (2014) menyatakan bahwa biji pepaya mengandung $25,1 \%$ protein kasar, 8,2\% abu, dan $45,6 \%$ serat kasar. Berdasarkan analisis fitokimia yang dilakukan oleh Adeneye dan Olagunju (2009), biji pepaya mengandung alkaloid, flavonoid, tanin, saponin, anthraquinones, dan anthosianosides. Tanin popular dengan sifat anti bakterinya dan dalam industri kulit tanin digunakan sebagai pengawet agar terhindar dari jamur serta mikroba yang merusak. Tanin dalam tubuh berperan sebagai anti diare atau infeksi usus (Banso dan Adeyemo, 2007). Dalam tubuh unggas, khususnya ayam, pemberian pakan yang mengandung 0,33\% tanin tidak membahayakan. Kadar tanin dalam pakan mencapai $0,5 \%$ atau lebih akan memberi pengaruh, yaitu dapat menekan pertumbuhan ayam karena tanin dapat menekan retensi nitrogen dan mengakibatkan menurunnya daya cerna asam-asam amino yang seharusnya dapar diserap oleh vili-vili usus (Widodo, 2005).

Minyak biji pepaya yang berwarna kuning diketahui mengandung $71,60 \%$ asam oleat, $15,13 \%$ asam palmitat, $7,68 \%$ asam linoleat, 3,60\% asam stearat, dan asam-asam lemak lain dalam jumlah relatif sedikit atau terbatas. Secara tradisional biji pepaya dapat dimanfaatkan sebagai obat cacing gelang, gangguan pencernaan, diare, penyakit kulit, kontrasepsi pria, bahan baku obat masuk

Tabel 1. Keunggulan itik MA

(eminence of MA duck)

\begin{tabular}{lccc}
\hline \hline \multirow{2}{*}{ Parameter } & \multicolumn{2}{c}{ Genotip (genotype) } \\
\cline { 2 - 4 } & $\mathrm{A}$ & $\mathrm{M}$ & $\mathrm{MA}$ \\
\hline Umur pertama bertelur (minggu) (sexual maturity (weeks)) & 24 & 25 & 22 \\
Berat telur pertama (g) (first egg weight (g)) & 55 & 53,7 & 56,7 \\
Berat badan pertama bertelur (g) (body weight at first laying (g)) & 1761 & 1616 & 1803 \\
Produksi telur/3 bulan (\%) (egg production/3 months (\%)) & 66,5 & 66,8 & 74,2 \\
Produksi telur/1 tahun (\%) (egg production/year (\%)) & 62,8 & 61,0 & 71,5 \\
\hline
\end{tabular}

A: Alabio, M: Mojosari, MA: Mojosari Alabio.

Sumber: Balitnak (2006) cit. Allaily (2006). 
angin dan sebagai sumber untuk mendapatkan minyak dengan kandungan asam-asam lemak tertentu (Warisno, 2003). Penelitian ini bertujuan untuk mengetahui kinerja itik Raja yang diberi biji pepaya dalam pakan.

\section{Materi dan Metode}

\section{Materi}

Ternak yang digunakan adalah 72 ekor itik Raja, setiap perlakuan terdapat 3 replikasi dan dalam setiap replikasi terdiri 6 ekor. Perlakuan diberikan pada itik berumur 7 hari. Pakan yang digunakan terdapat dua jenis yaitu untuk fase starter dan finisher yang mengacu pada standar NRC (1994). Alat yang digunakan dalam penelitian adalah perlengkapan kandang lengkap dengan tempat pakan dan minum, termohigrometer, blender, timbangan digital dan manual.

\section{Preparasi biji pepaya}

Biji pepaya (Carica papaya L.) yang digunakan adalah biji pepaya segar yang sudah dipisahkan dari daging buahnya dan tanpa proses pencucian. Biji pepaya segar dihaluskan dengan blender dan langsung dicampurkan ke dalam pakan.

\section{Pengelompokan ternak}

Itik Raja berumur 7 hari sebanyak 72 ekor ditempatkan pada 4 kelompok perlakuan penambahan biji pepaya dengan dosis berbeda, yaitu $\mathrm{T0}=0 \%$ biji pepaya dalam ransum (kontrol), T1 $=0,3 \%$ biji pepaya dalam ransum, T2 $=0,6 \%$ biji pepaya dalam ransum, T3 $=1,2 \%$ biji pepaya dalam ransum. Setiap kelompok perlakuan diberikan replikasi 3 kali dan masing-masing replikasi diberikan 6 ekor. Itik dipelihara sampai umur 45 hari.

\section{Pakan dan pemeliharaan}

Pakan yang diberikan adalah formulasi ransum untuk itik pedaging yang mengacu pada NRC (1994), terdapat 2 macam ransum, yaitu untuk fase starter dan finisher. Pemberian pakan dilakukan tiga kali sehari pada pukul $07.00,12.00$, dan pukul 16.00 WIB. Pakan diberikan secara terbatas dan minum diberikan secara ad libitum. Formulasi ransum pada penelitian ini seperti tersaji pada Tabel 2.

Variabel yang diamati adalah konsumsi pakan, pertambahan berat badan, dan konversi pakan.

\section{Analisis data}

Data hasil penelitian diuji statistik menggunakan Rancangan Acak Lengkap pola searah. Jika terdapat perbedaan yang nyata antar perlakuan maka diuji lanjut menggunakan Duncan's Multiple Range Test (Steel dan Torrie, 1993).

\section{Hasil dan Pembahasan}

Rerata berat awal, konsumsi pakan, pertambahan berat badan dan konversi ransum dapat dilihat pada Tabel 2. Hasil analisis statistik menunjukkan bahwa penambahan biji pepaya dalam pakan menurunkan konsumsi pakan, namun meningkatkan pertambahan berat badan, sehingga diperoleh konversi pakan yang lebih baik $(P<0,05)$.

Konsumsi pakan secara umum dipengaruhi oleh banyak faktor, antara lain ukuran tubuh, berat badan, jenis kelamin, tahap produksi, temperatur lingkungan dan kandungan energi ransum (North, 1984). Dalam percobaan ini, konsumsi pakan tanpa penambahan biji pepaya paling tinggi dibandingkan pakan yang diberi tambahan biji pepaya. Hal tersebut dikarenakan kandungan energi dari pakan yang diberi tambahan biji pepaya lebih besar dari pada yang tidak diberi tambahan biji pepaya. Semakin tinggi energi pakan maka konsumsi pakannya akan semakin rendah. Aravind et al. (2013) menyatakan bahwa biji pepaya memiliki rasa yang tajam dan pedas. Hal tersebut yang memungkinkan biji pepaya dapat menurunkan palatabilitas pakan sehingga konsumsi pakan menurun seiring dengan meningkatnya pemberian biji pepaya dalam pakan. Hal tersebut juga dapat dikaitkan dengan jumlah alat perasa pada itik yang lebih banyak dibandingkan ayam, burung dara, dan puyuh (Zuprizal, 2006). Bolu et al. (2009) menyatakan bahwa terjadinya penurunan konsumsi pakan pada ayam broiler yang pakannya disubstitusi biji pepaya pada level 10 dan $15 \%$.

Pertambahan berat badan adalah salah satu indikator dari pertumbuhan ternak yang mempengaruhi konversi pakan. Konversi pakan adalah perbandingan antara konsumsi pakan dengan pertambahan berat badan pada waktu yang sama (Rasyaf, 2004). Pertambahan berat badan merupakan indikator utama dalam pengukuran pertumbuhan sebagai landasan ukuran 
Tabel 3. Kinerja itik umur 45 hari (performance of 45 days old ducks)

\begin{tabular}{|c|c|c|c|c|}
\hline \multirow{2}{*}{ Variabel (variable) } & \multicolumn{4}{|c|}{ Perlakuan (treatment) } \\
\hline & T0 & T1 & T2 & T3 \\
\hline $\begin{array}{l}\text { Berat awal (g/ekor) } \\
(\text { initial weight }(g / h e a d))^{n s}\end{array}$ & $145,28 \pm 13,02$ & $144,39 \pm 16,70$ & $145,67 \pm 15,25$ & $144,67 \pm 13,60$ \\
\hline $\begin{array}{l}\text { Konsumsi pakan (g/ekor) } \\
\text { (feed intake }(\mathrm{g} / \mathrm{head}) \text { ) }\end{array}$ & $3426,57 \pm 44,87^{a}$ & $3414,40 \pm 43,04^{a}$ & $3389,34 \pm 62,35^{a}$ & $3207,78 \pm 99,65^{b}$ \\
\hline $\begin{array}{l}\text { Pertambahan berat badan (g/ekor) } \\
\text { (average daily gain (g/head)) }\end{array}$ & $1105,06 \pm 104,38^{b}$ & $1088,11 \pm 17,17^{\mathrm{b}}$ & $1265,17 \pm 58,20^{a}$ & $1222,83 \pm 70,16^{\mathrm{ab}}$ \\
\hline $\begin{array}{l}\text { Konversi pakan (feed conversion } \\
\text { ratio) }\end{array}$ & $3,12 \pm 0,26^{a}$ & $3,14 \pm 0,01^{a}$ & $2,69 \pm 0,17^{b}$ & $2,63 \pm 0,08^{b}$ \\
\hline
\end{tabular}

tidak optimal. Pertambahan berat badan yang naik secara signifikan seiring dengan penambahan dosis biji pepaya dalam pakan menunjukkan bahwa dalam hal ini biji pepaya juga berperan sebagai anthelmintika.

Biji pepaya dapat menjadi solusi anthelmintika alami bagi unggas, khususnya itik yang secara umum pemeliharaannya tradisional lebih rentan terhadap infeksi cacing. Beriajaya et al. (1996) membuktikan bahwa pemberian serbuk biji pepaya sampai dosis $3,0 \%$ berat badan pada domba yang diinfeksi Haemonchus contorus mampu menurunkan jumlah telur cacing tetapi tidak mengurangi jumlah cacingnya. Hal ini sejalan dengan yang dinyatakan oleh Setiaji (2003) bahwa pemberian infus biji pepaya sampai dengan dosis $30 \mathrm{ml} / \mathrm{kgBB}$ secara per oral pada ayam buras yang terinfeksi cacing secara alami mampu menekan produksi telur cacing Nematoda dan Cestoda, namun tidak dapat mengurangi jumlah cacingnya. Parashar dan Metha (1996) berhasil mengurangi jumlah cacing Oxyuris sebanyak 32$52 \%$ dengan memberikan biji pepaya pada mencit yang terinfeksi cacing tersebut. Selain sebagai anti bakteri, anthlemintik, biji pepaya juga sebagai anti fungi. Biji pepaya sebagai anti fungi dinyatakan oleh Singh dan Ali (2011) bahwa ekstrak metanol dari biji pepaya pada dosis 5,10 , dan $20 \mu \mathrm{g} / \mathrm{ml}$ memiliki aktivitas anti fungi terhadap Aspergillus flavus, Candida albicans, dan Penicillium citrinium. Dalam hal ini, aktivitas anti bakteri, anthelmintik, dan anti fungi dari biji pepaya dapat meningkatkan efisiensi pakan sehingga dapat meningkatkan rasio konversi pakan.

\section{Kesimpulan}

Penambahan biji pepaya dalam ransum hingga level $1,2 \%$ dapat me- ningkatkan kinerja itik Raja, konsumsi pakan lebih rendah, pertambahan berat badan meningkat sehingga konversi pakan cenderung menurun.

\section{Ucapan Terima Kasih}

Naskah ini banyak mendapatkan masukan dari Prof. Zuprizal dan Dr. Supadmo, untuk itu penulis menyampaikan terima kasih yang sebesar-besarnya.

\section{Daftar Pustaka}

Adeneye, A. A. and J. A. Olagunju. 2009. Preliminary hypoglycemic and hypolipidemic activies of the aqueous seed extract of Carica papaya Linn.in Wistar rats. Biol. Med. 1: 1-10.

Allaily. 2006. Kajian silase ransum komplit berbahan baku pakan lokal pada itik Mojosari Alabio jantan. Tesis. Institut Pertanian Bogor, Bogor.

Anonim. 2007. Standar Pakan Itik. Direktorat Jenderal Peternakan dan Kesehatan Hewan. Kementerian Pertanian, Jakarta.

Anonim. 2012. Statistik Peternakan dan Kesehatan Hewan 2012. Direktorat Jenderal Peternakan dan Kesehatan Hewan. Kementerian Pertanian, Jakarta.

Aravind, G., B. Debjit, S. Duraivel and G. Harish. 2013. Traditional and medicinal uses of Carica papaya. J. Med. Plant Stud. 1: 7-15.

Banso, A. and S. O. Adeyemo. 2007. Evaluation of antibacterial properties of tannins isolated from Dichrostachys cinerea. Afr. J. Biotechnol. 6: 17851787. 
Beriajaya, T. B. Murdiati, T. Kristianti, dan G. Adiwinata. 1996. Biji pepaya sebagai anthelminthic terhadap Haemonchus contortus pada domba. Prosiding Temu IImiah Nasional Bidang Veteriner, 1213 Maret 1996.

Bolu, S. A. O., F. E. Sola-Ojo, O. A. Olorunsanya and K. Idris. 2009. Effect of graded levels of dried pawpaw (Carica papaya) seed on the performance, haematology, serum biochemistry and carcass evaluation of chicken broilers. Int. J. Poult. Sci. 8: 905-909.

Hardjosworo, P. dan Rukmiasih. 1999. Itik Permasalahan dan Pemecahan. Penebar Swadaya, Jakarta.

Kusumaningtyas, P. 2012. Itik: Potensi Bisnis dan Kisah Sukses Praktisi. Penebar Swadaya, Depok, Jawa Barat.

Maisarah, A. M., R. Asmah and O. Fauziah. 2014. Proximate analysis, antioxidant and antiproliferative activities of different parts of Carica papaya. J. Nutr. Food Sci. 4: 2-7.

North, M. O. 1984. Commercial Chicken Production Manual. $3^{\text {rd }}$ edn. The AVI Publishing Company, Inc. Westport, Connecticut, USA.

NRC. 1994. Nutrient Requirement of Poultry. $9^{\text {th }}$ edn. Rev. National Academy Press, Washington DC.

Parashar, G. C. and R. K. Mehta. 1996. Effect of Buttea frandosa, Veronicaa anthelminthica and Carica papaya against Oxyurids in mice. Indian Vet. J. 43: 744-748.

Purba, M. dan P. P. Ketaren. 2010. Performa itik jantan MA jantan umur enam minggu dengan suplementasi santoquin dan vitamin $\mathrm{E}$ dalam pakan. Seminar Nasional Teknologi Peternakan dan Veteriner, Bogor.

Rasyaf, M. 2004. Beternak Ayam Pedaging. PT. Penebar Swadaya, Jakarta.

Setiaji, D. 2003. Efektivitas infus biji pepaya sebagai anthelmintik pada ayam buras terinfeksi cacing secara alami. Skripsi Fakultas Kedokteran Hewan, Institut Pertanian Bogor, Bogor.
Singh, O. and M. Ali. 2011. Phytochemical and Antifungal profiles of the seeds of Carica papaya L. Indian J. Pharm. Sci. 73: 447-451.

Steel, R. G. D. dan J. H. Torrie. 1993. Prinsip dan Prosedur Statistik: Suatu Prosedur Pendekatan Biometrik. Edisi ke-2. Penerbit PT Gramedia, Jakarta.

Subhan, A. 2009. Pengaruh penggunaan sagu kukus (Metroxylon spp.) dan tepung keong mas (Pomacea spp.) sebagai pengganti jagung kuning dalam pakan terhadap penampilan itik jantan Alabio, Mojosari, dan hasil persilangannya. Tesis Fakultas Peternakan, Universitas Gadjah Mada, Yogyakarta.

Suharsono, 1987. Respon Telur terhadap Berbagai Kondisi Lingkungan. Direktorat Pembinaan Penelitian dan Pengabdian Masyarakat. Direktorat Jenderal Pendidikan Tinggi, Depdikbud, Jakarta.

Sukadana, I. M., S. R. Santi, dan N. K. Juliarti. 2008. Aktifitas antibakteri senyawa golongan triterpenoid dari biji pepaya (Carica papaya L.). Jurnal Kimia 2: 1518.

Susanti, T. 2003. Strategi pembibitan itik Alabio dan Mojosari. Tesis Fakultas Peternakan, Institut Pertanian Bogor, Bogor.

Suyadi. 1992. Pengaruh tingkat kandungan ransum terhadap titer antibodi Newcastle Disease, kadar albumin serum dan performan ayam pedaging. Tesis Universitas Brawijaya, Malang.

Warisno. 2003. Budidaya Pepaya. Kanisius, Yogyakarta.

Widodo, W. 2005. Tanaman Beracun dalam Kehidupan Ternak. UMM Press, Malang.

Zuprizal. 2006. Nutrisi Unggas. Jurusan Nutrisi dan Makanan Ternak. Fakultas Peternakan, Universitas Gadjah Mada, Yogyakarta. 